\title{
The Impacts of Patent Layering on Public Health: Lessons from India to Nigeria
}

\author{
Great Ijomah \\ Ph.D Candidate, Department of Private and Property Law, Faculty of Law, University of Benin, Benin City, Edo \\ State, Nigeria, P.M.B 1154
}

\begin{abstract}
This paper is intended to be a contribution towards the improvement and efficiency in patenting pharmaceutical inventions, particularly in developing countries. The paper seeks to evaluate the concept of patent layering and its allied concepts against the backdrop of the prescribed duration of patent vis a- vis the argument for competition (free market), and the monopoly or exclusive right of patentee with the aim of ascertaining its overall effect on the right of the general public to have access to good health using pharmaceutical industry as a case study. It shall be demonstrated that the practice is antithetical to general public access to medicine (drugs). The paper will suggest and propose a policy shift by way of amending the provisions in the Nigeria Patent and Designs Act dealing with requirement for patentable invention by setting higher standards for novelty particularly on improvement of existing patent. The paper shall contend that failure for the developing countries, like Nigeria to amend their Patent laws will have suffocating effect on the public health sector and risking the life of poor patient whose meager income may not afford these drugs.
\end{abstract}

Keywords: Intellectual property, Patent, Medicine, Drugs, Patent layering, Evergreening

DOI: $10.7176 / \mathrm{JLPG} / 88-20$

Publication date: August $31^{\text {st }} 2019$

\subsection{Introduction}

Globally, over two billion people are out of reach of medicine (drugs) they need especially the life saving ones. Huge advances in global health are being made toward internationally agreed global health targets. Nevertheless, new and complex challenges continue to emerge, demanding sustained commitment and deeper cooperation from many different stakeholders particularly the pharmaceutical companies.

Since patents confer exclusive rights regarding the production, sale and use of the patented invention, they can be used to restrain competition and set prices higher than those that would have existed if competitive products were available. This is the very purpose of the patent system, which is generally justified as necessary to encourage investment to develop new products and processes. Those who argue against patent believe that patent unjustifiably stifles competition by promoting monopoly ${ }^{1}$. This is because a patentee can stop others from from replicating his invention thereby making him the only player in the market and accordingly giving him the leverage to dictate or influence the price of the product beyond the reach of the consumers2.

Proponent of free market believes that the short term duration of patent is necessary to remove the monopoly of the patentee and open the market for others to invest in. This free market and competition is what is resisted by the patentee through the device or antics of patent layering3

Given the substantial effects that patents can have on public health, the criteria applicablein examining the grant of pharmaceutical patents are extremely relevant for public health policies. Policy makers should in this regard be aware that decisions relating to the grant of patent can directly affect the health and lives of the people of the country where the patent is granted and enforced.

Nigeria is gradually advancing into manufacturing drugs locally, the drive for local drug production is in top gear as lofty sum and concerted effort are being made to upgrade production facilities and strengthens capacities with international collaboration to acquire the World Health Organization (WHO)'s prequalification needed for international competition4. Since the nation is in the right direction to reaching its desire stage of competiveness, there is therefore the need to address the challenges bedeviling the industry in other jurisdiction which patiently await Nigeria.

The promotion of pharmaceutical research and development is a crucial health intervention. For instance, in a landmark innovation, the National Institute for Pharmaceutical Research and Development (NIPRD), with

Jonathan J. Darrow, "Debunking the Evergreening Patents Myth", Harvard Law Record, Vol. 131 (6) (2010) 12; Access to Medicine Index 2018 methodology report available on https://accesstomedicinefoundation.org/access-to-medicine-index accessed 08/08/19

2 Adam Karbowski and JacekProkop, "Controversy over the Economic Justifications for Patent Protection", International Conference on Applied Economic (ICOAE), Procedia Economics and Finance, Vol. 5 (2013) 393 - 402

3 Rajarshi Banerjee, "The Success of, and Response in, India's Law against Patent Layering", Harvard International Law Journal, Recent Development, Vol. 54, (May 2013) 5 - 8

4 OdinakaAnudu, "Nigerian Pharmaceuticals eye $70 \%$ of Local Drug Market", https:businessday.ng/real-sector/article/nigerianpharmaceuticals-eye-70-of-local-drug-market/ accessed on July 29, 2019 
government help, initiated and completed the research and development of a phytomedicine (Niprisan/Nicosan) for the management of sickle cell anaemia. The product has been granted orphan drug status by both the United States Food and Drug Administration and the European Medicine Evaluation Agency. The fact that Niprisan/Nicosan is the only therapy which will be accessible to over 10 million sickle cell anaemia patients in sub-Saharan Africa will give a boost to the local pharmaceutical industry and NIPRD is now developing other phytomedicines for the management of prevailing priority disease ${ }^{1}$.

Since drug development involves a lot of unknown risks and behind every successful drug molecule there is an extensive research and development which consumes several years and resources. Most countries provide 20 year exclusivity for a patented drug, of which considerable amount of this time is lost during the regulatory application and approval process.

It is therefore expected for any innovator firm to resort to undue practices such as patent layering so as to recover the heavy cost incurred by them by constantly ever-greening the invention via process patent. This practice are not in any way humanitarian as their sole aim is to maintain their monopoly by increasing number of patents in their patent portfolios thereby dictating the cost of such drugs in perpetuity.

Developing countries like Nigeria must resist these abysmal practices by updating their laws using Indian Patent Act, 2005 as a guide. It places a higher burden on a patentee to show the exact nature of newness of the innovation in the patents before it can be registered. This is perhaps why drugs in India are cheap because they have freed themselves from the iron grip of patent layering. Nigerian Patent and Designs Act should be reviewed to provide for stricter requirement or criteria for registering process patent. ${ }^{2}$

\subsection{Conceptual Clarifications \\ 2.1 Invention}

The ordinary meaning of "invention" relates to the output of an intellectual activity in the form of new knowledge of a technological nature. A patentable device or process created through independent effort and characterized by an extraordinary degree of skill or ingenuity. To invent is "to create by thought, originate (new method, instrument, e.t.c" 3 . It also suggests a distinction between creations and mere discoveries and, more generally, between inventions and other subject matter that is not the outcome of an inventive process ${ }^{4}$.Invention embraces the concept of nonobviousness.

\subsection{Medicine/Drugs}

Medicine in this context means a substance that is used in treating disease or relieving pain and that is usually in the form of a pill or a liquid. On the other hand, drug is a substance intended for use in the diagnosis, cure, treatment, or prevention of disease. This paper seeks to use the two terms interchangeably.

\subsection{Benchmark for the Grant of Patent}

Patent is an exclusive privilege not necessarily a monopoly to reward the true and first invention of new inventions. It is a right granted under the law to protect an invention that is novel or basically an improvement over some existing processes ${ }^{5}$. It is a set of exclusive rights granted by a State to an inventor or assignee for a limited period of time in exchange for detailed public disclosure of an invention. It is generally related to manufacturing or production of technological processes. Patents are the most important way by which inventors, innovators protect their inventions. It is alicence conferring the sole right to the exclusion of others from making, using, or selling an invention for a set period of time usually specified by statute. However, upon the expiration of the patent, it enters into public domain.

Section 1 (1) of the Patents and Designs Act ${ }^{6}$ provides that subject to this section, an invention is patentable -

a. If it is new, results from inventive activity and is capable of industrial application; or

b. If it constitutes an improvement upon a patented invention and also is new, results from inventive activity and is capable of industrial application.

Policymakers are faced with a complicated landscape when deciding where to set the bar or benchmark for

\footnotetext{
Global United Nations Industrial Development Organization Project, "Strengthening the Local Production of Essential Generic Drugs in Least Developed and Developing Countries" Pharmaceutical Sector Profile Nigeria, Vienna 2011 page 63

2 Adam B. Jaffe and Josh Lerner, "Innovation and Its Discontents: How Our Broken Patent System is Endangering Innovation and Progress, and What to do About It", Princeton University Press, (2004) 7.

Bryan A. Garner, Blacks Law Dictionary, Ninth Edn, p. 901; The Concise Oxford Dictionary, 1989. P. 527

4 Many patent laws make such a distinction. For instance, Article 52 (2) of the European Patent Convention stipulates that, "[T] he following in particular shall not be regarded as inventions within the meaning of paragraph 1: (a) discoveries, scientific theories and mathematical methods; (b) aesthetics creations; (c) schemes, rules and methods for performing mental acts, playing games or doing business, and programs for computers, (d) presentation of informations'

5 ZoeLynnTurrill, "Finding the Patent Balance: The Novartis Glivec case and the TRIPS Compliance of India's Section 3(d) Efficacy Standard", Georgetown Journal of International Law, Vol. 44 (2013) 1556 - 1559

6 Cap 344, Laws of the Federation of Nigeria, 1990
} 
patentability, as patients benefit from the innovation funded by pharmaceutical companies when those companies discover life-saving drugs, but they will be harmed if patents are never allowed to expire so that low cost generics can enter the market. On the other hand, it will be idle to pretend that there have been no beneficial fall-outs from patent. Prominent amongst these benefits are reward for the inventor's intellectual dexterity as well as encouraging research and development. Accordingly, if patents are not granted on their products, pharmaceutical companies lose years of monopoly profits and are not able to fund the research and development necessary for innovation. Patent therefore seeks to find a compromise between the inventor and the State ${ }^{1}$.

\subsection{Duration of Patent}

Traditionally, patent are durable for 20 years. Section 7 of the Patent and Design $\mathrm{Act}^{2}$ provides that a patent shall expire at the end of the twentieth year from the date of the filing of the relevant patent application. It therefore means that after 20 years the patent lapses and the invention falls into public domain and anybody can adapt it.

The linchpin of the foregoing provision is that at the expiration of the 20 years the invention falls into public domain. At this point, developing countries can adapt and gradually improve their pharmaceutical industry which has the effect of lowering the price of such drugs through competition, a move that big pharmaceutical industries are opposed to. Due to this seemingly limited scope or short life span of patent, patentee contrived patent layering as a scheme to prolong their patents beyond the statutory period. This they do by cashing in by the requirement of improvement for the grant of process patent. Through this disguised improvement, they get a fresh grant of patent for another 20 years or more and in the long run, sustain the product patent indirectly. The effect of this is that they have monopoly power in respect of particular industry ${ }^{3}$.

\subsection{Patent Layering}

Drug patent layering is a marketing strategy that multinational pharmaceutical companies use to keep their products updated, with the intent to maintain patent protection for longer periods than would normally be permissible under the law ${ }^{4}$. It refers to increasing the life span of the patent beyond 20 years to reap the benefits for a much longer period of time.

Layering refers to a variety of legal and business strategies by which technology producers with patent over products that are about to expire retain royalties from them, by either taking out new patents (for example over new delivery systems, strength, indication or new pharmaceutical mixtures/formulations), or by paying for delay or buying out competitors, for longer periods of time than would normally be permissible under the law. Once this is done, the improvement is registered on a new process patent which gives additional life or extends the duration of product patent already registered ${ }^{5}$.

A common belief is that patents are normally granted to protect new invention, but while the number of patents obtained annually is small and declining, thousands of patents are granted for pharmaceuticals. The reason, being that a large number of patent cover minor modification of older existing drugs ${ }^{6}$. For instance, it was reported that in 2008 alone, South Africa granted 2442 patents, while in sharp contrast; Brazil only granted 278 patents between 2003 and 2008 which had the effect of delaying the entry of generic medicines into the South African market.

This problem will be easy to solve if Nigeria, South Africa and other developing countries amends the provisions in the Patents Act dealing with patentable invention by setting higher standards for novelty particularly on improvement of existing patent as is done in India ${ }^{7}$.

According to the report of the National Institute for Health Care Management in the United States, in the 12 years period 1989 - 2000, just $153(15 \%)$ of all new drug approvals were medicines providing a significant clinical improvement ${ }^{8}$.

T. Amin and A.S. Kesselheim, "Secondary Patenting of Branded Pharmaceuticals: A Case Study of How Patents on Two HIV Drugs Could Be Extended For Decades", Health Affairs, Vol. 31(10), (2012) 7; Lisa P. Lukose, "Patent Evergreening: Law and Ethics", $7^{\text {th }}$ International Conference on Information Law and Ethics”, (22 - 23 Feb., 2016) 1

Ibid

Aditya Kant, "Section 3 (d): New Indian Perspective", Journal of Intellectual Property Rights, Vol. 14, September (2009) 385 - 396 ;

John R. Thomas, "Patent Evergreening: Issues in Innovation and Competition", Congressional Research Service, November 13, 2009 pg 1

5 R. Chalmers, "Evergreen or Deciduous? Australian Trends in Relation to the 'Evergreening' of Patents", Melbourne University Law Review, Vol. 30, (2006) 21; M. Tornvall, "The Use and Abuse of Patents - Evergreening in the Pharmaceutical Sector", LL.M. Thesis submitted to the Faculty of Law, Lund University, (2013); S. Kumar, N. Shukla et al, "Evergreening of Patents and the Indian Patent Law", SSRN, No. 1420003, 2009; E. Hore, "Patently Absurd: Evergreening of Pharmaceutical Patent Protection under the Patented Medicines", (Notice of Compliance) Regulations of Canada's Patent Act, CGPA, 2004

6 See Correa (2004)

7 Carlos Correa, “The Novartis Decision by India's Supreme Court: A Good Outcome for Public Health”, South Bulletin, Issue 75, 7 October 2013. The Court, however, emphasized that 'in whichever way section 3(d) may be viewed, whether as setting up the standards of "patentability" or as an extension of the definition of "invention", it must be held that on the basis of the materials brought before the Court, the subject product, that is, the beta crystalline form of ImatinibMesylate, failed the test of section 3(d) of the Act (para. 190).

8 National Institute for Health Care Management (2002) 
It has been used by manufacturers of particular drugs to restrict or prevent competition from manufacturers of a generic equivalent, thus, extending the patent period and seizing the generic drug manufacturing, which overall incurs additional cost burden that can be very significant for the public health budgets and the consumer ${ }^{1}$. This practice also widens the gap between innovation and access to drugs because competition leads to innovation $^{2}$. Once the generic drugs are launched, the price of the patented drug can drop by as much as $90 \%{ }^{3}$.

It is noteworthy that patent layering is not only limited to pharmaceutical products, it is applicable to all categories of patent but prominent in process patent. However, because of drive mode access to health care and medicare, there is some conscientious effort in some jurisdictions to curtail the incidences of patents layering in the pharmaceutical industry.

\subsection{The Impact of the Agreement on Trade - Related Aspects of Intellectual Property Rights (TRIPS) on Access to Public Health}

With the creation of the World Trade Organization (WTO) in 1994, the most comprehensive treaty on intellectual property rights to date was established: the Agreement on Trade - Related Aspects of Intellectual Property Rights (TRIPS). This Agreement links intellectual property and trade issues for the first time and provides a multilateral mechanism for settling disputes between States. The TRIPS Agreement requires all WTO Members to adopt in their laws minimum universal standards for almost all rights in this field, such as copyrights, patents, and trademarks ${ }^{4}$.

It seeks to standardize the benchmarks for the protection of intellectual property rights. Additionally, it creates a platform for the reciprocal recognition and protection of patents by the signatory countries. Article 27 specifically acknowledged the right of the "Host Countries" to set out the benchmark for recognizing and protecting the patent of the product of the foreign country ${ }^{5}$. It provides that patents shall be available for any inventions, whether products or processes, in all fields of technology, provided that they are new, involve an inventive step and are capable of industrial application.

By signing the TRIPs Agreement the developing countries were encouraged to open their market for product from the developed countries through the grant of patent by requiring signatory countries to enact laws to recognize and protect the patents of such products, making the developed countries who are at the forefront of research and innovation opposed to any form of restriction to the duration of patent in the pharmaceutical industry and by extension opposed to the effort to curtail patent layering ${ }^{6}$.

Most multinational pharmaceutical industries sought to prolong and sustain patents in their drug through the scheme of patent layering. That is, for every drug they have invented they kept creating a semblance of improvement on the drug by suggesting new method of producing the drug or new methods of applying the drugs either way, they were able to register a new patent for their new method of using the $\operatorname{drug}^{7}$

Once the new patent was registered no other person can replicate the new process in question. With this they sustain their monopoly in the production of the drug in question thereby depriving the local entrepreneurs from reproducing such drug using the new method or process for another 20 years. With this, the price of the drug remains high beyond the reach of the average citizens in these developing countries making such important drug like Cancer and HIV vaccines unaffordable . $^{2}$

The fallout of this Agreement is that developing countries were naively entrapped into a mandatory obligation to reorganize and sanction any scheme design as patent layering, this is without prejudice to the interest of developing countries. Developing countries like Nigeria with weak patentable criteria ends up promoting layering at the detriment of her public health ${ }^{9}$

Carlos Correa, "Guidelines for the Examination of Pharmaceutical Patents: Developing a Public Health Perspective", International Centre for Trade and Sustainable Development, January 2007.

2 Aaron S. Kesselheim, "Intellectual Property Policy in the Pharmaceutical Sciences: The Effect of Inappropriate Patents and Market Exclusivity Extensions on the Health Care System", The AAPS Journal, Vol. 9 (3) (2007) 308.

3 John LaMattina, "Spending on Drugs will drop as top sellers go Generic", Forbes, available on https://www.google.com/amp/s/www.forbes.com/sites/johnlamattina/2016/04/14/u-s-drug-prices-to-decline/amp/ accessed on $19 / 06 / 2019$

4 See Velasquez and Boulet for detailed legal analysis of the minimum standards under the TRIPS Agreement; see UNCTAD - ICTSD Project on Intellectual Property Rights and Sustainable Development, "Resource Book on TRIPS and Development", Cambridge University Press, 2005 (available at http://www.iprsonline.org/unctadictsd/ResourceBookindex.htm) accessed on 03/08/19

${ }^{5}$ Article 27.1 of the TRIPS Agreement stipulates that patents "shall be available for any inventions ... provided that they are new, involve an inventive step and are capable of industrial application". It leaves WTO Members leeway to interpret and define, in good faith, within their legal systems, the concept of 'invention' and the patentability requirements.

6 TerjeGudmestad, "Patent Law of United States and the United Kingdom: A Comparison", Loyola of Los Angeles International and Comparative Law Review, Vol. 5, (1982) 173

John H. Barton, "Reforming the Patent System", Science, Vol. 287, (17 March 2000) 1933-1934

${ }^{8}$ Reuven Brenner, "Must All Patents Last for 20 Years? A Flexible System that Recognizes the Needs of Different Industries Might Lead to Less Legal Conflict", April 23, 2013, http://online.wsj.com/article/SB10001424127887324504704578413154212218668.html accessed on 2/02/2018

9 Mike Hutchins, "Using Interlocking Additional Early Stage Patents to Improve and Extend Patent Protection", International Journal of 
The Agreement has also substantially limited the freedom that countries enjoyed to design and implement their own intellectual property systems.

Prior to the negotiation of the TRIPS Agreement, more than 50 countries did not provide patent protection for pharmaceuticals, many provided only process, and not product patents and the duration was much less than 20 years in many countries ${ }^{1}$. This Agreement introduced a unifying standard for all signatory members.

It is now generally acknowledged that the current regime of patent protection, as "globalised" by the TRIPS Agreement, has a significant impact on the pharmaceutical sector. It has also been observed that the standards specified in the TRIPS Agreement are not necessarily appropriate for countries struggling to meet health and development needs.

Accordingly, the UK Commission on Intellectual Property Rights (CIPR) in its 2002 report cautioned countries "to ensure that their intellectual property protection regimes do not run counter to their public health policies and that they are consistent with and supportive of such policies"2

Growing concerns over the way international trade agreements and, particularly, the WTO TRIPS Agreement, can restrict access to medicines led to the adoption of the Doha Ministerial Declaration on the TRIPS Agreement and Public health. The declaration marked an important milestone in the debate on intellectual property rights and access to medicines, in affirming that the TRIPS Agreement should be interpreted and implemented in a manner supportive of countries' right to take measures to protect public health and promote access to medicine. In this regard, the Declaration enshrines the principles that agencies such as WHO have publicly advocated and advanced, namely, the reaffirmation of the right of WTO Members to make full use of the flexibilities of the TRIPS Agreement in order to protect public health and promote access to medicines ${ }^{3}$.

An important flexibility in this respect is the right of WTO Members to define the patentability criteria as referred to under the TRIPS Agreement in accordance with their particular national priorities. This may be an important tool for the promotion of genuinely new and inventive pharmaceutical products ${ }^{4}$.

The TRIPS patent balance is based on standards drawn from U.S. law, and developing countries on their part assert that the TRIP Agreement did not take into account their unique interests ${ }^{5}$. Thus, developing countries have advanced a number of "balance adjusters" to alter the TRIPS standard to meet their needs ${ }^{6}$. One balance adjuster is India's Patent Act, 2005

\subsection{The Way forward for Developing Countries}

The way forward for developing countries is to evolve a legislative scheme that will make it difficult for these patentees or foreign manufacturers to evergreen their patents in their countries. This they can do my taking the benefit of the proviso of Article 27 of TRIPs which permits the signatories countries to enact their local laws to restrict patent in matter of health and medicine ${ }^{7}$.

It should be appreciated, however, that patents that result from original filings, rather than continuation applications, continue to enjoy a term of 20 years based upon their own filing date. For example, suppose that a brand-name pharmaceutical firm files a patent application claiming an active ingredient in 2020, resulting in a patent that expires in 2040. In 2025, the same firm files a second, original patent application claiming an extended release formulation of that active ingredient. If that second patent issues, it will not expire until 2045. As a result, strategies that scholars characterize as layering or evergreening remain viable and potent despite statutory changes to the patent term.

The foregoing challenge can be solved by amending and broadening the non-patentable invention provisions in the Patent Law and raising the standard for patenting process patent.

\subsection{India Patent Act, 2005}

It is heartening to note that India has successfully devised a scheme to curtail patent layering or ever greening in

Medical Marketing, Vol. 3, (2003) p. 212-215. For other examples, see A. Kapczynski, C. Park and B. Sampat, "Polymorphs and Prodrugs and Salts (Oh My!): An Empirical Analysis of 'Secondary' Pharmaceutical Patents”, PLoS ONE, Vol. 7, Issue 12, (2012) 70.

See UNCTAD -ICTSD Project on Intellectual Property Rights and Sustainable Development, "Intellectual Property Rights: Implication for Development", Policy Discussion Paper, Geneva (2003)

Commission on Intellectual Property Rights (2002)

3 Frederick M. Abbott, "Intellectual Property and Public Health: Meeting the Challenge of Sustainability", Global Health Working Paper of the Graduate Institute, Geneva, (2011) p. 1

4 Alexander G. Watson, "International Intellectual Property Rights: Do TRIPS Flexibilities Permit sufficient Access to Affordable HIV/AIDS Medicines in Developing Countries?", Boston College International and Comparative Law Review, 32(2009) 148

5 Stephanie Greene, "A Prescription for Change: How the Medicare Act Revises Hatch-Waxman to Speed Market Entry of Generic Drugs", Journal of Corporation Law, Vol.30 (2005) 309

6 Janice M. Mueller, "Taking TRIPS to India - Novartis, Patent Law and Access to Medicines", New English Journal Medical,Vol 356, (2007) 541

Alison R. McCabe, "A Precarious Balancing Act - The Role of the FDA as a Protector of Public Health and Industry Wealth", Suffolk Law Review, Vol 36. (2003) 787; Matthew Avery, "Continuing Abuse of the Hatch-Waxman Act by Pharmaceutical Patent Holders and the Failure of the 2003 Amendments", Hastings Law Journal, Vol.60, (2008) 171 
its pharmaceutical industry. These schemes have helped in no small way to cushion off the heavy impact of patent layering in the pharmaceutical industry. The Indian government did this by introducing Section 3 (d) of the India Patent Law, 2005 ${ }^{1}$. The section was enacted with the intent of discouraging the abysmal practice of the pharmaceutical companies from ever greening of patents. The section reads as follows: "the mere discovery of a new form of a known substance which does not result in the enhancement of the known efficacy of that substance or the mere discovery of any new property or new use for a known substance or of the mere use of a known process, machine or apparatus unless such known process results in a new product or employs at least one new reactant"

This section was introduced as a measure to curtail the abuse of process patent registration in India ${ }^{2}$. It places a higher burden on a patentee to show the exact nature of newness innovation in the patents before it can be registered.

Consequently, new discovery of additional input, dosage mere discovery of chemical component additive in salt are not acceptable as improvement in process patent ${ }^{3}$.

The Act emphasized that the patentee should show that an improvement of his product has changed the character of the product especially on the efficiency of the product.

It will suffice to say that section 3(d) was hinged on efficiency as the benchmark for the acceptance and registration of an invention as a process patent.

\subsection{Reactions from Multinational Pharmaceutical Companies}

The effort by Indian Patent and Design Commission did not go down well with the multinational pharmaceutical companies in the developed countries. They accused India of breaching the provision of Article 27 of TRIPs Agreement and therefore sought to strike down Section 3 (d) of the India Patent Law who also viewed the effort as an attempt to stifle their business. They argue that section 3(d) is incompatible with TRIPS law which encourages reciprocal acceptance and sanctifying of patent by signatory countries including India ${ }^{4}$.

The high point of this, is the celebrated case of Novartis's Drug Imatinib A. G v. Union of India ${ }^{5}$, the plaintiffs was a drug company for the cure of leukemia, when their patent was about to elapse they tried to improve the composition of the drug and applied for patent. The registrar of patent denied them registration on the ground that there is no convincing evidence that the product is effective.

Commendably, the Supreme Court of India held that the drug in issue is no more than a new version of an old medicine which did not provide significantly enhanced therapeutic benefit therefore, not patentable. This decision discourages patent layering. The court interpreted the law putting economics in view, as medicine (drugs) will be cheaper and affordable to the public. We submit therefore that this is the major reason why Nigerian elites prefer medical treatments in India.

The court further held that Section 3d is not inconsistent with TRIPS Agreement and upheld the Registrar's decision refusing the registration 6 .

Another notable development was the 2007 opinion of the U.S. Supreme Court in KSR International Co. $v$. Teleflex Inc. ${ }^{7}$ The KSR opinion addresses one of the fundamental requirements for obtaining a patent, the standard of nonobviousness. Under this standard, "[a] patent may not be obtained ... if the differences between the subject matter sought to be patented and the prior art, are such that the subject matter as a whole would have been obvious ... to a person having ordinary skill in the art...."

Many observers believe that the KSR opinion raised the standard of nonobviousness, making it harder to obtain a patent ${ }^{9}$. If this view is accurate, patent layering may become a less viable tactics, because patents to improvement inventions may be more difficult to procure from the U.S Patent and Trademark Office (USPTO). ${ }^{10}$

Interestingly, Argentina, Brazil, Japan, Mexico and Philippines have recently adopted the Indian model in regulating patent layering. Argentina adopted guidelines to examine patent applications for pharmaceuticals

Patents (Amendment) Act, 2005, No. 15 of 2005 - WIPO

NagarajMannikeri and VidyaBhaskar Singh, Patent Trolling and Evergreening: Unethical Acts or Malpractices?; available at http://www.foxmandal.com/wp-content/uploads/2015/06/Malpractices-in-the-Patent-system-final-june-15-21.pdf accessed on $19 / 02 / 2018$

3 Philip Grubb, Patents for Chemicals, Pharmaceuticals and Biotechnology: Fundamentals of Global Law, Practice and Strategy, (Clarendon Press, Oxford, 1999).

Leighton Howard, "Formulations Patents in Pharmaceutical Development", Journal of Generic Medicines, Vol. 5, (2008) 365-370

Novartis A.G., \&Anors v. Union of India \& Others (2007) 4 MLJ 1153

Vikas Bajaj and Andrew Pollack, India's Supreme Court to Hear Dispute on Drug Patents, New York Times, (March 6, 2012) available at http://www.nytimes.com/2012/03/07/business/global/indias-supreme-court-to-hear-long-simmering-dispute-on-drug-

patents.html?pagewanted $=$ all\& $\mathrm{r}=0$ accessed $20 / 02 / 2018$

550 U.S. 398 (2007)

35 U.S.C \& 103 (a) (2006)

Rebecca S. Eisenberg, "Pharma's Nonobvious Problem", Lewis \& Clark Law Review, Vol.12 (2008) 375

Christopher M. Jackson, "The War on Drugs: How KSR v. Teleflex and Merck v. Integra Continue the Erosion of Pharmaceutical Patent Protection”, Capital University Law Review, Vol.36 (2008) 1029 
inventions. The guidelines provide specific instructions regarding the application of the patentability standards in the pharmaceutical industry. It instructs patent examiners to reject new use, new form and new formulation patents, and specify a number of other frivolous changes to drugs which will no longer be acceptable.

Philippines on the other hand amended her patent law in 2008 and introduced a section similar to the referred section 3 (d) in the Indian Patent Act, but the guideline adopted by the patent office may lead to a less rigorous application of the patentability requirements than in India. While in the latter the concept of enhanced efficacy as a condition of patentability is understood to allude to the "therapeutic efficacy" of a drug, in Philippine it may encompass any of the "advantageous properties" (e.g, bioavailability, stability, solubility among others) exhibited by the new form of a known substance with the purpose of upping or heightening the standards for obtaining a patent ${ }^{1}$.

In 2012 Australia $^{2}$ adopted the "Raising the Bar Act" which, inter alia, raised the requirements for patentability and disclosure and expanded the grounds for re-examination of a granted patent to all substantive grounds considered during examination ${ }^{3}$.

The above development points to the fact that developing countries are gradually embracing the innovation introduced by the Indian Patent Act, by stiffening the requirements for patentable inventions particularly with respect to process patent. We also recommend and call for Nigeria to emulate or borrow a leaf from India's legal framework in other to resist these abysmal practices. This is perhaps the reason why drug is cheaper in India, because they have freed themselves from the stranglehold of layering (ever-greening $)^{4}$. In 2015, it was reported that 20,000 Nigerians seek medical treatment in India annually, 50\% of Nigerians that travel to India go there for medical treatment ${ }^{5}$.

\subsection{Conclusion}

From all the aforesaid, efforts have been made in this paper to examine the current positions of the law as regards the requirement for process patent in Nigeria. We have highlighted the impacts of patent layering to public health. The paper also examined that if developing countries like Nigeria, fails to amend their patent laws, to provide stiffer requirement for process patent, the pharmaceutical industry will be controlled by few multinational companies in perpetuity, thereby forestalling competition and promoting monopoly which will make access to drugs (medicine) out of reach to the poor patients whose meager income may not afford such life saving drugs. Solutions via recommendations have been proffered in this paper that Nigeria should as a matter of fact amend her Patent and Designs Act to provide for stronger statutory benchmark for process patent as done in India.

David M. Gersten, "The Quest for Market Exclusivity in Biotechnology: Navigating the Patent Minefield”, NeutroRxVol. 2 (2005) 572

T. Faunce and Joel Lexchin, "Linkage Pharmaceutical Evergreening in Canada and Australia", Australia-New Zealand Health Policy, Vol. 4 (8) (2007) 3; Australian Government, Pharmaceutical Patents Review. Draft Report, April 2013, p. 159, available at http://www.ipaustralia.gov.au/about-us/ip-legislation-changes/review-pharmaceutical-patents/... Accessed 03/02/2018

3 Carlos M. Correa, "Tackling the Proliferation of Patents: How to Avoid Undue Limitations to Competition and the Public Domain", Research Paper, Vol. 52 (South Centre, August 2014) 6; P. Vure, "Polymorph Patents": How Strong they are Really?" International Journal of Intellectual Property Management, Vol.4 (4), (2011) 297-306.

4 News Wires, "Nigerian Shiite leader granted bail for medical treatment abroad", available on https://www.google.com/amp/s/amp.france24.com/en/20190806-nigeria-shiite-leader-zakzaky-bail-medical-treatment accessed on $09 / 08 / 2019$

5 Premium Times, "https://premiumtimesng.com/news/top-news/175164-20000-nigerians-seek-medical-treatment-indiaannually.html accessed on 09/08/2019 